\title{
A Review of "Values in Translation: Human Rights and the Culture of the World Bank," by Galit A. Sarfaty
}

Amanda Craig

Indiana University Maurer School of Law, amacraig@indiana.edu

Follow this and additional works at: https://www.repository.law.indiana.edu/ijgls

Part of the Banking and Finance Law Commons, Human Rights Law Commons, and the International Law Commons

\section{Recommended Citation}

Craig, Amanda (2014) "A Review of "Values in Translation: Human Rights and the Culture of the World Bank," by Galit A. Sarfaty," Indiana Journal of Global Legal Studies: Vol. 21 : Iss. 1 , Article 15.

Available at: https://www.repository.law.indiana.edu/ijgls/vol21/iss1/15

This Book Review is brought to you for free and open access by the Law School Journals at Digital Repository @ Maurer Law. It has been accepted for inclusion in Indiana Journal of Global Legal Studies by an authorized editor of Digital Repository @ Maurer Law. For more information, please contact rvaughan@indiana.edu.

\section{$\Psi$}

JEROME HALL LAW LIBRARY

INDIANA UNIVERSITY

Maurer School of Law
Bloomineton 


\title{
A Review of Values in Translation: Human Rights and the Culture of the World Bank by Galit A. Sarfaty
}

\begin{abstract}
AMANDA CRAIG*
In Values in Translation, Galit Sarfaty depicts an unfortunate but ostensible truth about the World Bank, in which the economics discipline reigns supreme: frame your issue in economic terms, and the World Bank may act on it; but frame your issue in economic terms, and you may forfeit your issue's essential core. As such, wide adoption of a human rights policy at the World Bank may require human rights to be analyzed and implemented empirically, devoid of their complicated political and legal contexts, which may ultimately undercut the protection of those rights. Moreover, in leaving unresolved her catch-22, Sarfaty demonstrates the complexity of global governance-due not only to competing values within the system but also to bureaucratic dynamics embedded in ambitious international institutions.

Such bureaucratic dynamics include organizational culture and ineffective translation of knowledge among disciplines, which have stifled the World Bank's development and adoption of certain policies, including human rights. Detailing and explaining these dynamics is a central goal of Sarfaty's book. In recent decades, she explains, many other international organizations, private financial institutions, and aid agencies have adopted human rights agendas, but amidst such increased consciousness, the Bank is an anomaly. Despite both external and internal pressure to do so, the Bank does not consider the impact of its lending on human rights, require client countries to comply with international treaty obligations, or suspend projects when client countries abuse human rights. ${ }^{1}$ In short, Sarfaty, an anthropologist and legal scholar, unpacks why the Bank has not done so in Values in Translation.
\end{abstract}

* J.D. 2014, Indiana University Maurer School of Law; M.Sc. in Refugee and Forced Migration Studies, University of Oxford; B.S. in Journalism, Northwestern University.

1. Galit A. Sarfaty, Values in Translation: Human Rights and the Culture of THE WORLD BANK (2012), at 23-50.

Indiana Journal of Global Legal Studies Vol. 21 \#1 (Winter 2014)

(C) Indiana University Maurer School of Law 
She first highlights efforts both outside and within the Bank to push it to adopt a human rights policy or implement a human rights impact assessment for its own projects. After noting that nongovernmental organizations have pressured corporations to develop such policies and the Bank to develop other social and environmental policies, she explains that there is actually "a lack of consensus among advocates over whether to pressure the Bank to adopt a human rights agenda . . . "2 Advocates fear that the Bank may "co-opt" human rights (as it has environmental issues) or pass an "inadequate human rights policy," which would then be very difficult to substantially revise. ${ }^{3}$ In addition, the Bank's internal efforts-including an interdisciplinary human rights-focused working group in the 1990s and a human rights report, workshop, and institution-wide task force in the 2000s-could not gain sufficient traction. 4 According to Sarfaty, both institutional and normative challenges explain failed internal campaigns. Because task force members did not receive from the Bank's president or board a clear mandate to move forward, they acted cautiously and "made only symbolic gestures rather than concrete steps toward change." 5 In addition, it was difficult for employees from different sectors and disciplinary backgrounds to reach consensus, and the Legal Department and regional departments fought to control the human rights agenda. ${ }^{6}$

But Sarfaty argues that the more significant, underlying problemwhich has allowed these institutional challenges to completely stymie progress-is "ambivalence over the conflicting relationship between human rights and the prevailing neoliberal ideology within the Bank."7 Neoliberal capitalism, to which the Bank adheres, opposes or embraces human rights depending on circumstance; for instance, its core belief in individual freedom is consistent with property rights but not with distributive justice. Reflecting these contradictions, the Bank draws arbitrary lines around certain rights. Those that are consistent with its ideology are considered implementable by the Bank, and those that are inconsistent with its ideology are referred to as "political"-an attribute signifying that implementation is beyond the Bank's mandate. ${ }^{8}$ For instance, the Bank considers forced labor and employment discrimination against women but does not take into account freedom of
2. Id. at 35 .
3. Id. at 33-35.
4. Id. at $36-42$.
5. Id. at 43 .
6. Id. at $44-46$.
7. Id. at $42-43$.
8. Id. at $4 ; 52-60$. 
association or the right to collective bargaining, referring to the former as apolitical and the latter as political. ${ }^{9}$

After identifying the Bank's ambivalence as the ultimate cause of its failure to develop and implement a human rights agenda, Sarfaty delves into a deeper analysis of the institutional restraints that confound efforts to overcome such ambivalence. She cites political constraints, including, most importantly, the influence of large borrower countries, like China, that oppose adopting a human rights agenda and deeply divide the Bank's governing board. ${ }^{10}$ In addition, she explains that the Bank's Articles of Agreement require that the Bank ignore politics when lending money.11 However, she also demonstrates that "the deeply divided board is not as critical an obstacle to human rights adoption as it may seem," and other issues, like corruption, have been depoliticized and then adopted by the Bank. ${ }^{12}$ In fact, the Bank itself has claimed the right to decide whether an issue is political; for instance, former Bank President James Wolfensohn declared that

corruption is ... not political but it is social and economic and, therefore, I am allowed to talk about it. And if ... politicians think that it is political, that is not my problem. I think it is social and economic. Therefore, I can talk about it.13

Moreover, two general counsels at the Bank authored opinions acknowledging the "centrality of human rights within development" and the importance of interpreting the Articles flexibly over time. ${ }^{14}$

Most scholarship focuses exclusively on the legal and political obstacles that the Bank faces in attempting to adopt a human rights policy, but Sarfaty demonstrates that the impact of such obstacles is limited and then considers alternative institutional obstacles. Specifically, she analyzes the significant impact of organizational

9. Id. at 47 .

10. Id. at 51-56.

11. More specifically, the Articles of Agreement state that "[t]he Bank and its officers shall not interfere in the political affairs of any member; nor shall they be influenced in their decisions by the political character of the member or members concerned. Only economic considerations shall be relevant ...." In addition, they state that "[t]he Bank shall make arrangements to ensure that the proceeds of any loan are used only for the purposes for which the loan was granted, with due attention to considerations of economy and efficiency and without regard to political or other non-economic influences or considerations." Id. at 58 .

12. Id. at 56, 59-60.

13. Id. at 4.

14. Id. at 59,63 . 
culture on the development of a human rights agenda. With unusual access to the Bank's programs and staff, she contemplates how programs are researched, designed, implemented, and incentivized. For one, she notes that Bank employees are not trained on how to choose among competing priorities if, for instance, a project is benefitting people whose government is nonetheless unfairly locking up dissidents. ${ }^{15}$

She also describes how the Bank's incentive system discourages employees from creating projects that consider human rights issues. The Bank favors financially expansive and quickly approved projects, in part because getting money out the door is easier to measure than a project's actual "contribution to results." 16 This bias is exacerbated by the structure of assignments in the Bank; employees generally move from unit to unit "every three to seven years," making long-term assessment of projects difficult and the tying of promotions to long-term outcomes nearly impossible. ${ }^{17}$ In addition, employees have learned to "refrain from carrying out projects that will trigger safeguard policies"like environmental or indigenous peoples policies-since they may "delay the progress of a loan and increase its expense."18

Sarfaty then emphasizes yet another organizational culture issue: the ways in which knowledge is created and translated by professionals representing various academic disciplines. While acknowledging that a range of perspectives and goals among unique individuals means that disciplines and their frames of reference are dynamic and may often overlap, she argues that the economic discipline uses particularly distinct language. Especially within the World Bank, the persistence of this distinct language is likely the result of economists' position relative to that of individuals from other disciplines. She writes that economists represent the "dominant subculture" of the Bank-that economists' "expertise ranks as the most valuable," and their "language is the dominant mode of communication and rationality." 19

The Bank has seemingly attempted to compensate for this unevenness by adopting a "matrix" organizational structure in which employees in different geographic and functional units cross-report; for instance, an employee in operations may be responsible to bosses in a country-management unit, a thematic research unit (e.g., poverty, the environment), and a sector-management unit (at headquarters). ${ }^{20}$ The

15. Id. at $77-78$.

16. Id. at 79 .

17. Id. at 80 .

18. Id. at 87.

19. Id. at 96 .

20. Id. at 89-90. 
matrix system is intended to "balance potentially conflicting objectives," including those among disciplines. ${ }^{21}$ However, employees find the system "difficult and confusing," and management scholars have argued that it has produced turf battles among units and loss of accountability. ${ }^{22}$

In any case, economists continue to dominate, and anthropologists, sociologists, and lawyers "struggle to reconcile their norms, priorities, and methodologies" with those of economists. ${ }^{23}$ In 2005, the Bank's Social Development Department organized a day-long training on its own irrelevance. Sarfaty recognized that the Department's 'biggest challenge was semantic: they had to bridge the communication gap with economists by measuring results and using indicators." ${ }^{44}$ However, she did not discover a similar training session that would encourage economists to learn to speak the language of noneconomists.

Rather, economists seek from other disciplines empirical work that demonstrates "causal links between human rights and economic growth." 25 Yet, Sarfaty explains that framing human rights in ways that resonate with economists may have detrimental effects. For instance, economists may prefer projects that are designed through an "instrumental" framework, which considers "human rights as a means to an end," rather than an "intrinsic" framework, which considers "human rights as an end in itself." 26 Comparing HIV/AIDS projects that adopted intrinsic and instrumental frames, she demonstrates that the former project resulted in much wider human rights protection than the latter. ${ }^{27}$

Instead of adopting an instrumental frame, Sarfaty recommends that the Bank continue to pursue its most recent "incremental, underthe-radar strategy" in which lawyers focus on pilot human rights projects in willing environments rather than advocating for an operational policy that would be incorporated into existing programs and require explicit management support. ${ }^{28}$ She finds such an incremental approach preferable to human rights losing its "essential core" through depoliticization and delegalization (though she acknowledges that human rights are already entering the Bank "through an instrumental framework"). ${ }^{29}$ To demonstrate these

21. Id. at 90 .

22. Id. at $90-91$.

23. Id. at 94 .

24. Id. at 95 .

25. Id. at 126-27.

26. Id. at 117-18.

27. Id at $120-23$.

28. Id. at 129 .

29. Id. at 15, 132, 137. 
potential negative effects, she analyzes the Bank's efforts to mainstream anticorruption, which required its depoliticization and "translation into an economic logic," resulting in an implementation "that is flawed at best and destructive to the Bank's mission at worst." 30 As such, Sarfaty concludes that depoliticizing human rights "may be a necessary first step" before the issue can be mainstreamed in "an economic institution like the Bank," but she contends that it will have to be repoliticized "before real organizational change can occur." 11

She also asks why the economist subculture is so dominant within the Bank and discovers a "broader institutionalization of economics" that poses a deeper challenge to the implementation of human rights. ${ }^{32}$ She explains that economists' numbers "serve as a technology of distance," and their authority is derived from their capacity to overcome that distance and the physical or social barriers that it implies. ${ }^{33}$ Numbers have achieved "prestige and power" in our modern world because, "in the context of intense disagreement, suspicion, and skepticism," they enable state bureaucrats "to achieve uniformity and public trust, and to dispel the notion that their decisions were arbitrary and biased since they lacked the mandate of a popular election." 34 In addition, the global circulation of capital, globalization of economics, and globalization of the law have created "opportunities for economists to enter legal arenas worldwide." 35 Moreover, the Bank itself "has facilitated the global expansion of capital and the diffusion of economic paradigms, not only within borrower countries but also within the bureaucracy itself." 36 Considering the dominance of economic paradigms, then, repoliticizing an issue like human rights will likely be very difficult unless the "clash of normative rationalities" that exists between economics and human rights-which Sarfaty also frames as a clash between the market and social democratic liberalism-is more effectively bridged both within and beyond the Bank. ${ }^{37}$

30. Id. at $135,136$.

31. Id. at 137.

32. Id. at 98 .

33. Id.

34. Id. at 99-100.

35. Id. at 100 .

36. Id.

37. Id. at 8. 